\title{
The Determinants of Non-Performing Loans in the Polish Banking Sector - the Household Loans Portfolio
}

\author{
SŁAWOMIR I. BUKOWSKI \\ Department of Business and International Finance, \\ Kazimierz Pulaski University of Technology and Humanities in Radom \\ B. Chrobrego Street, 31, Radom 26-600 \\ POLAND
}

\author{
ANETA M. KOSZTOWNIAK \\ Department of Monetary Economics, \\ SGH Warsaw School of Economics \\ al. Niepodległości 162, Warsaw 02-554 \\ POLAND
}

\begin{abstract}
The study aims to identify changes in non-performing household loans (NPLs) and their main determinants in the Polish banking sector for the period 2009-2021. Specifically, we look at the main determinants of creditworthiness of households which determine the possibility of repayment of principal installments and interest within the prescribed period. The results of the VECM model confirm the considerable significance of GDP per capita, gross salaries and lending rates to NPL loans of households. The results of the response function show a positive impact of GDP per capita and lending rates on NPLs and a negative impact of real salaries on NPLs. The decomposition of variance in the forecast period confirms an increased level of explanation of NPL by GDP per capita, gross salaries, and the lending rates.
\end{abstract}

Key words: non-performing loans (NPLs), loan portfolio quality, debt, households, banking crises, VECM, Poland

Received: May 20, 2021. Revised: December 21, 2021. Accepted: January 12, 2022. Published: January 14, 2022.

\section{Introduction}

Monitoring the quality of the portfolio, including household loans, in the banking sector results from prudential regulations, because NPLs can cause monetary crises that can turn into financial crises (Ghosh, 2015). According to Handley (2010) and Ivanovic (2016), NPLs can be used as an indicator of banking crises as they affect a country's economic growth by reducing credit development. Low NPLs indicate a strong monetary system in a country, while high NPLs indicate a weak financial situation. A growing level of non-performing loans in the longer term will affect commercial banks first and then the entire economy of a country (Souza and Feijó[1]). In addition, rising NPLs are impacting banking efficiency and causing banking crises (Vouldis and Louzis [2]). NPLs will block interest income, limit investment openings, and cause liquidity crises in the financial system, resulting in bankruptcy problems and economic slumps. For these reasons, it is imperative to identify the factors that influence NPLs to reduce NPL levels for financial stability and economic goals (Stijepović, [3]). An increasing liquidity risk at a bank may also be an effect of NPLs (Quadahet. el. [4]).

The problem of non-performing loans for economies is noticed by the European Commission (EC) (Kasingeret al. [5], which has announced strategies to combat non-performing loans. The first plan was announced by the ECOFIN Council in July 2017. This plan was then extended with a new package of measures in March 2018 and a capital markets recovery package in July 2020. The outbreak of the COVID-19 pandemic, like the global financial crisis (2007), may negatively affect household incomes and thus stimulate the growth of non-performing loans. Therefore, it is important to identify the main determinants of credit deterioration. Bank outstanding loans to total gross loans according to the World Bank (2021) show significant differences in the banking sectors of EU 
countries (including 36.4\% Greece, $17.1 \%$ Cyprus, 6.6\% Bulgaria, 6.2\% Portugal, 3.8\% Poland, and $1.1 \%$ Germany in 2019).

In a financial market such as in Poland (bankingoriented), banks play a key role in the sustainability of the banking system (Moradi et al., 2016). Considering that the share of loans to households in Poland accounts for $43 \%$ of total loans (NBP, 2021) and their value is approx. 35\% of GDP in 2021 (BIS [6]), it is important to monitor them.

The aim of the study is to indicate changes in the level of non-performing loans (NPLs) for households and their main determinants in the Polish banking sector in 2009-2021. The following questions are formulated: 1) How have NPL rates changed in the household loan portfolio in the analyzed period. Did these changes indicate an improvement or deterioration in the quality of the loan portfolio in the Polish banking sector? 2) Which of the explanatory variables had the strongest impact on the changes in the NPL ratio and what was their trend over time?

\section{Problem Formulation Literature Review}

\subsection{The main problem}

As the growth of NPLs has a negative impact not only on the banking sector but on the entire economy, a constant verification of the factors of NPL change is necessary. In the case of large economies, problems in a banking system may also spread to neighboring countries as part of the spillover effects. The main problem is to identify the main factors influencing changes in NPLs and to identify the strength and type (positive/negative)of this influence. Considering that most authors conduct research for a whole portfolio, they fail to the structure of loan portfolios broken down into loans to households and enterprises. This means that when the structure of a loan portfolio changes, the factors explaining NPLs may be different, or their impact may change to a significant extent. Therefore, these authors focus on a specific portfolio of loans to households.

\subsection{Literature Review}

The National Bank of Poland (NBP) and other institutions, e.g., the International Monetary Fund (IMF), state that loans would be considered NPLs if they do not produce interest and principal for a minimum of 90 days. The NPL rate is calculated as the ratio of non-performing loans (impaired loans) and advances to the gross value of total loans and advances (NBP [6]). The main reasons for high NPLs are weak credit procedures, incompetent credit specialists, high markup spreads, devefective credit principles and lack of a borrower monitoring policy. NPLs are a major indicator of credit risk that affects the banking system of a country.

The rise in NPLs in the last decade has caught the attention of many scholars around the world, who try to explain this phenomenon. The explanatory variables are mainly macroeconomic and bank-related. Studies regarding the factors that determine the level of NPLs show that a real increase in GDP usually translates into higher levels of income, improving the financial capacity of borrowers (Marcinkowska et.al., [8], Kosztowniak [9]). However, on the other hand, when the economy is below normal conditions or in a recession, the level of NPLs may increase due to a resulting rise in unemployment, with borrowers facing major difficulties to repay their debt (Salas and Suarina, [10]; Fofack, [11]; Hada et. al. [12]).

Klein [13] investigates determining factors and their impact on NPLs and on the macroeconomic performance of Central, Eastern and South-Eastern European (CESEE) countries for the period between 1998 and 2011, using the time series analysis. He finds that NPLs respond to macroeconomic conditions, such as unemployment, GDP growth, and inflation and highlights that the high NPLs in these countries affect the economic recovery negatively. Moreover, NPLs study results for 10 transition countries (Central and Eastern Europe) over the period 2006 and 2016 and use dynamic panel estimations to show that GDP growth and inflation are both negatively and significantly correlated with the level of NPLs, while unemployment is positively related to NPLs. The export growth shows largely non-significant results, indicating that NPLs within our sample were mainly affected by domestic conditions rather than external economic shocks (Mazreku et. al.[14]).

Exchange rates, interest rates and inflation are other macroeconomic factors that impact the quality of a bank's activities. Exchange rate fluctuations may have a negative impact on the quality of assets, especially in countries with a large amount of foreign currency loans. The same is true of interest rate increases, particularly in the case of loans with 
flexible interest ratea (Louzis et al., [15]; Zaman and Meunier [16]). On the one hand, higher inflation may ease debt compensation by affecting the real value of unpaid credit, while, on the other hand, it may also reduce the real income of unprotected borrowers. In countries where credit rates are flexible, higher inflation may lead to higher rates resulting from monetary policy actions to fight inflation (Nkusu, [17]). According to Salas [10], banks in the EU have created permissive lending conditions to attract customers. Low interest rates, rising house prices and a stable economic environment characterized the "precrisis" period. Regarding the Greek banking market, (Louzis, Vouldis and Metaxas) [2]) find that the real GDP growth rate, unemployment rate and lending rates have a strong negative effect on the NPL level, interpreting them as a sign of poor banking management.

The size of NPLs plays a key role in the stability of the banking sector of a country. The factors that explain the NPLs contain very important information for banks. Among the banking variables of NPLs, researches focus on return on assets (ROA), efficiency of a bank and bank capital. Godlewski [18] investigates the association between NPLs and return on assets (ROA) and states that the lower the rate of ROA, the higher the NPLs and vice versa. Boudriga et al. [19] confirm from their study that there is a negative association between ROA and NPLs. Dimitrios et al. [20] investigate various determinants of NPLs in the euro banking system and conclude that ROA has a significant impact upon NPLs. Rachman et al. [21] conclude that highly profitable banks have lower NPLs due to their better advancing activity and effective credit supervision systems. Berger and DeYoung [22] conclude that a decrease in the cost efficiency of commercial banks in the United States would contribute to increasing loan defaults in future. Insufficient control of a loan portfolio increases risk and NPLs. Fiordelisi et al. [23] examine the various factors that increase the risk level in the EU banks and conclude that a decreasing efficiency increases the risk level of banks in future. Furthermore, the efficiency and performance factors have an influence on NPLs in the Greek banking sector (Louzis et al., [2]). Rachman et al.[21] state that operating efficiency does not influence NPLs.

The effect of bank capital on NPLs works in the opposite direction. For one part, the incentivised managers of low capitalized banks tend to get involved in high-risk investments and give loans that are issued without a proper credit rating and monitoring (Keeton, 1999). On the other hand, banks with a high level of capital tend to give loans easily as they know that due to these loans banks are not going to be bankrupt and fail; therefore, banks are highly engaged with these kinds of risky credit activities suggesting a positive association between capital and NPLs (Rajan [24]). Moreover, the capital adequacy ratio (CAR) shows the ability of an organization to face abnormal losses and to survive that situation. Makri et al. [25] also state that there is a negative association between CAR and NPLs. Constant and Ngomsi [26] claim that NPLs and CAR are positively correlated.

Bank profitability and sustainability can only be assured with a proper flow of interest income generated through the lending function of banks. However, a bank's capital decreases together with its health, which is becoming fragile, enhancing the trend of NPLs. Therefore, banks are required to take proactive action to deal with a bad choice of borrowers by identifying and understanding the macroeconomic factors that contribute to the rise of classified credit in the banking system (Anjom and Karim [27] and Dimitrios et. al. [28]). According to Khuhair and Mardini [29]), NPLs also depend on the effectiveness of asset management by bank staff who can use the bank's IT infrastructure to assess creditworthiness (Meshref [30]).

\subsection{The changes of household loans and NPLs}

The value of household loans in the banking sector in Poland showed a general upward trend in Q1.2009-Q2.2021 (from PLN 398.2 million to PLN 768.4 million), especially in the period Q3.2012Q2.2021 (from 7.5\% to 6.0\%). This means that NPLs for households were lower compared to the NPLs for enterprises (7.0-8.0\%) by around 2.0 p.p. During the COVID-19 pandemic, the upward trend in loans was maintained, except for temporary declines in Q2.2020 and Q1.2021 (q/q). Maintaining the demand for loans was a result of programs implemented by commercial banks, i.e., solutions aimed at facilitating the situation of borrowers in a difficult financial situation caused by the COVID-19 epidemic (Fig. 1). 
Fig. 1. Loans impaired and without impairment of households and NPL ratio in Poland

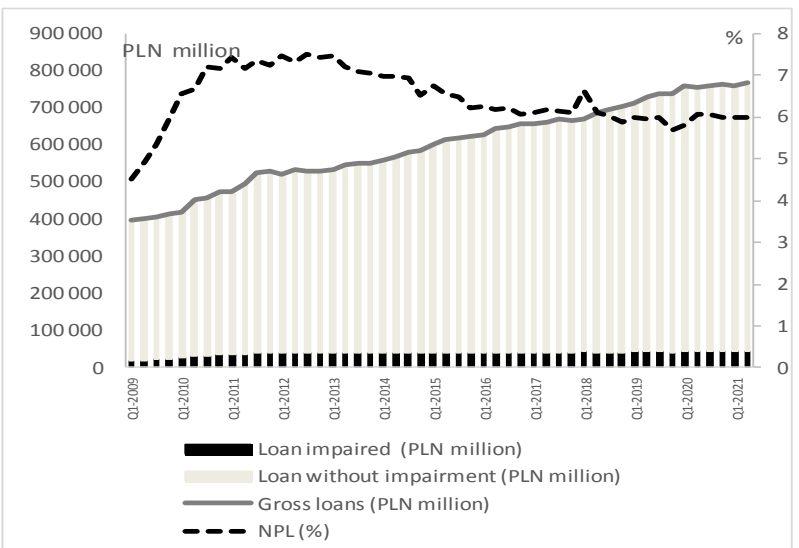

For nearly a decade, NPLs have stabilized at the level of $6.0 \%$. Despite the pandemic, the rate of NPLs is not rising. One of the reasons is a decline in the average interest rate on commercial banks' loans to households from $5.1 \%$ in Q1.2020 to $3.6 \%$ in Q2.2021 amid a lowering of the basic NBP rates (Fig. 2).

Fig. 2 NPLs and average interest rate on loans to households and non-profit institutions serving households (\%)

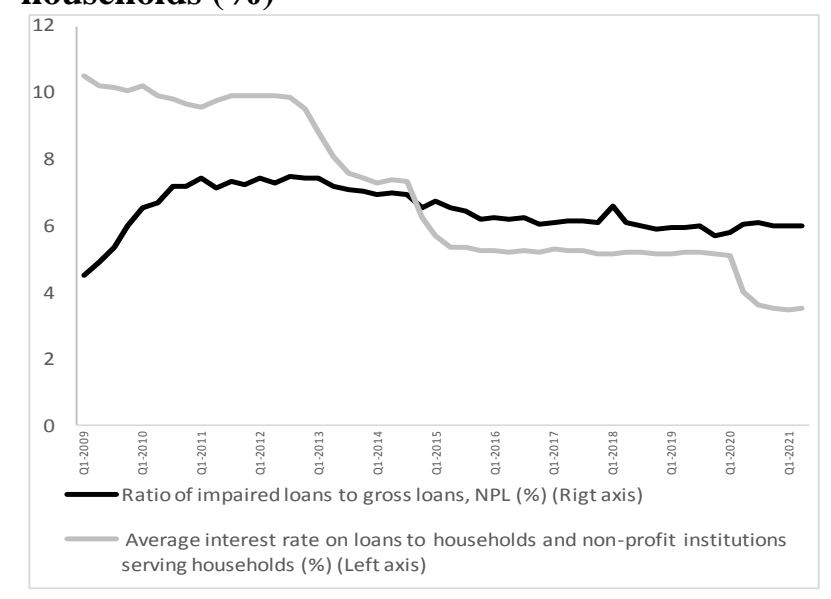

\section{Results and Discussion}

\subsection{Data and Methodology}

In the methodological approach used by the NBP [6], household loans are available to: private persons, individual entrepreneurs, individual farmers, and non-commercial institutions operating for the benefit of households. The article attempts to assess the quality of the portfolio of loans granted to households, therefore, respectively, impaired loans and total loans granted to these households (included in the so-called phase III, portfolio B) are considered. The research is based on statistics from the NBP, Central Statistics Office (CSO), and Organisation for Economic Co-operation and Development (OECD Internet databases) (Fig. 3).

Fig. 3. Time series of the model variables
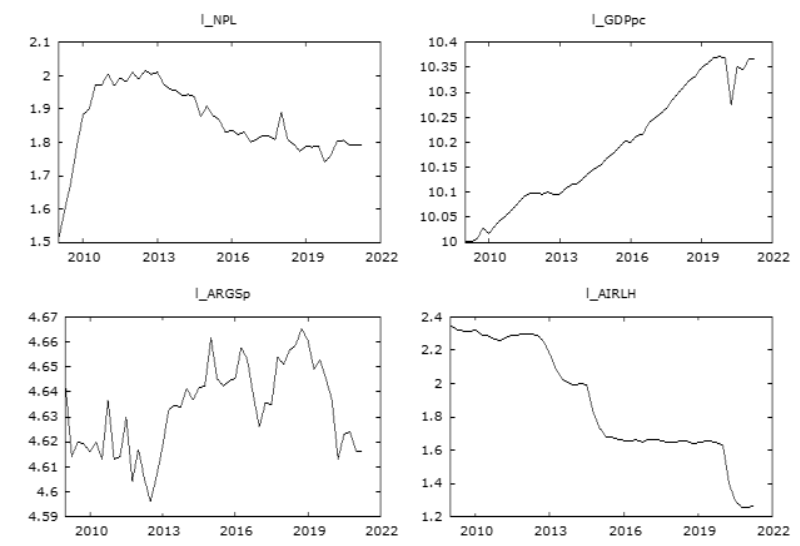

The specificity of the base equation is developed as a formula:

$$
\begin{aligned}
& \ln N P L_{t}=a_{1}+a_{2} \operatorname{lnGDPpc_{t}}+a_{3} \operatorname{lnARGSp}_{t}+ \\
& a_{4} \Delta A I R L H_{t}+u_{t}
\end{aligned}
$$

The explained variable: $N P L_{t^{-}}$The nonperforming loan ratio.

Explanatory variables:

$G D P p c_{t}-$ Gross domestic product per capita

$A R G S p$ - Average monthly real gross salary (analogous period of the previous year $=100$ )

AIRLH - Average interest rate on loans to households and nonprofit institutions serving households

Ln - natural logarithm

$\Delta$ - first differences

$U-$ random factor

$t$ - period

The model is constructed using the backward rolling regression method. The methodology of changes in the quality of the loan portfolio corresponds to the methodologies used by central banks, e.g., by the NBP and the IMF ([31], Matthewes, Guo and Zhang [32], Maggi and Guida [33], Mazreku et.al.[14]). The study period includes quarterly data for the period Q1.2009-Q2.2021. The methods used are known from literature on international economics and international finance and econometric methods like the VECM model (Vector Error Correction Method) including the impulse response functions. The expected influence 
of the explanatory variables on the explained variable (NPLs) is presented in Table 1 (Annex).

The model data is verified on the basis of tests for unit roots, e.g., Augmented Dickey-Fuller (ADF) test, and cointegration is tested using the Engle Granger test. The test results confirm the applicability of the VECM model. The ADF test confirms the unit-root null hypothesis: $a=1$, by testing without constant the estimated value of (a-1): -0.317433 , test statistic: $\tau(4)=-4.38122$ with a critical value equal to -2.93 (with the significance level of 5\%), -3.58 (the significance level $1 \%$ ), and asymptotic p-value $0.05665, \quad 1$ st-order autocorrelation coefficient for e: 0.026 .

The lag order for the VAR/VECM model is based on an estimation of the following information criteria: the Aikake information criterion (AIC), Schwartz-Bayesian information criterion (BIC), and Hannan-Quinn information criterion (HQC). According to these criteria, the best, that is, minimal values of the respective information criteria are: $\mathrm{AIC}=2, \mathrm{BIC}=1$ and $\mathrm{HQC}=1$, with the maximum lag order 4. Ultimately, the lag order 2 is accepted. To analyze stability of the VAR model, a unit root test is applied. The test indicates that in the analyzed model equation roots in respect of the module are lower than one, which means that the model is stable and may be used for further analyses (Fig. 4).

\section{Fig. 4. VAR inverse roots in relation to the unit circle}

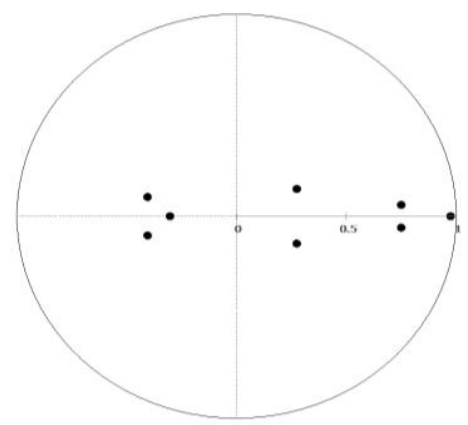

Due to the occurrence of the unit element in all the time series and the existence of cointegration among the model variables, it is possible to extend and transform the model into vector error correction models (VECM).

\subsection{VECM model and results}

Co-integration is verified, justifying the use of the VECM model for the lag order 2 and co-integration of order 1. In accordance with the Granger representation theorem, if variables $y_{t}$ and $x_{t}$ are integrated to the order of I (1) and are co-integrated, the relationship between them can be represented as a vector error correction model (VECM) (Piłatowska [34]).

The general form of the VECM can be written as:

$$
\begin{aligned}
\Delta Y_{t}= & \Gamma_{1} \Delta Y_{t-1}+\Gamma_{2} \Delta \mathrm{Y}_{t-2}+\ldots+\Gamma_{k-1} \Delta Y_{t-k+1} \\
& +\pi Y_{t-k}+\varepsilon_{t}= \\
= & \sum_{i=1}^{k-1} \Gamma_{i} \Delta Y_{t-i}+\pi Y_{t-k}+\varepsilon_{t}
\end{aligned}
$$

where:

$$
\begin{aligned}
& \Gamma_{i}=\sum_{j=1}^{i} A_{j}-\mathrm{I}, i=1,2, \ldots, k-1, \Gamma_{k}=\pi= \\
& -\pi(1)=-\left(\mathrm{I}-\sum_{i=1}^{k} A_{i}\right)
\end{aligned}
$$

and $\mathrm{I}$ is a unit matrix.

The results of the VECM model confirm for NPLs (the explained variable) the validity of changes in the previous deviations of NPLs, GDP per capita and relative salaries determining the creditworthiness potential and interest rates on loans. The EC1 index (containing the evaluation of the error correction index) confirms that the strongest correction of deviations from the longterm equilibrium occurs in the case of the NPL equation. Here, $38.66 \%$ of the imbalance from the long-term growth path is corrected by the short-term adjustment process. The significance of the other variables is weaker, i.e., GDP per capita $(0.15 \%)$, real gross salaries $(0.07 \%)$, and interest rate on loans $(0.04 \%)$. The sign of EC1 indicates that the increase in GDPpc and real salaries contributes to a reduction of NPLs (negative relation). The impact of changes in NPLs from previous periods on changes in NPLs in the new periods is also negative. There is a positive relationship between the interest rates on loans and NPLs. However, it should be kept in mind that these rates during the system study period were falling together with the NPLs. The results of the determination coefficient (R2) indicate a moderately good adjustment of the VECM model equations to the empirical data. The results of the Durbin-Watson (DW) test do not confirm the existence of a significant residual autocorrelation (Table 2, Annex).

The research results presented in the article are consistent with the results of such authors as: Salas and Suarina [10], Fofack [11], Mazreku et. al.[14]. 


\subsection{Impulse response functions}

The analysis of the NPL response to impulses from the explanatory variables confirms the strength of the influence of these impulses' changes over time. About 5-10 quarters of the forecast, the impact of the explanatory variables on NPLs showed a stabilization (constant). The results of the impulse response function indicated that NPL showed positive but declining responses to own NPL impulses and negative responses to gross salaries. This proves a weaker transfer of previous problems with non-performing loans to subsequent loans and indicates a positive impact of salaries growth on the quality (service) of loans.

NPLs reacted with an increased force to impulses from GDPpc and interest rate on loans to households (AIRLH). The effect of GDPpc on NPLs varied over time. At the beginning, as expected, GDPpc contributed to a decline in NPLs. However, the increase in GDPpc was conducive to an increase in demand for loans (including mortgage for the purchase of real estate). The NPLs showed increasing trends in response to changes of AIRLH, i.e., a stronger impact over 0-5th quarter and stabilization after the 10th quarter (Fig. 5).

Fig. 5. Impulse response functions

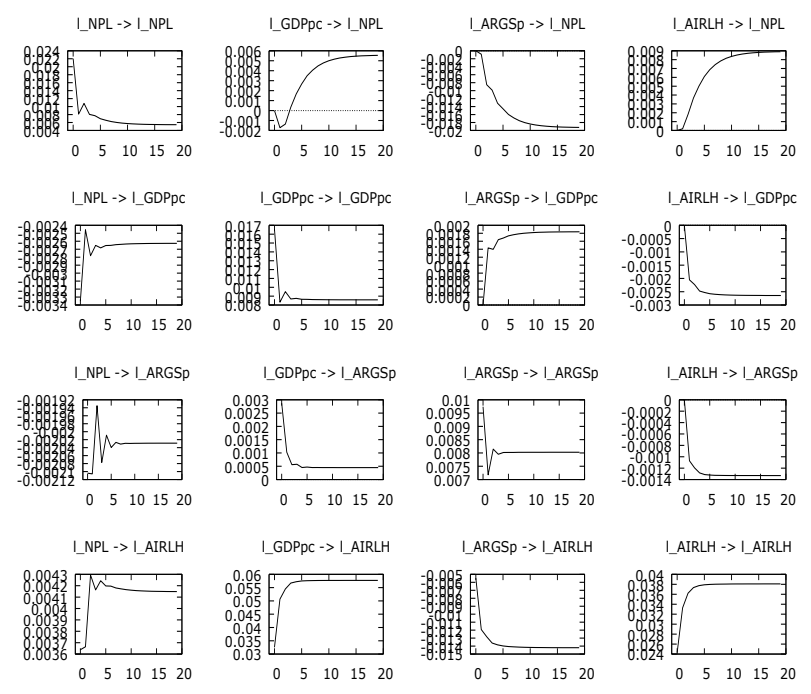

\subsection{The decomposition of variance}

The decomposition of the NPL variance considering the explanatory variables for 20 periods (quarters) confirms the forecast of changes in the degree of NPL explanation. The results of NPLs decomposition indicate that in the 1st period, these changes are fully accounted for with their own forecast errors. In the $4^{\text {th }}$ period (one year), their own changes diminish $(79.1 \%)$ and grow in significance like GDPpc (0.5\%), ARGSp (18.5\%), and AIRLH (1.8\%). In the following periods, NPLs' own changes fall in the $20^{\text {th }}$ period ( 5 years) by $16.1 \%$, while the degree of explanation on the part of GDPpc rises to $4.6 \%$, AIRLH to $13.3 \%$, and ARGSp to $65.9 \%$.

The significant degree of explanation of NPLs by changes in real salaries (to 66\%) indicates the importance of salaries (current incomes) for servicing loans. Thus, the economic development (salary growth) and the decline in the unemployment rate are of key importance for the quality of household loan portfolios. These results are confirmed by the results of Mazrek [14], Salas and Surina [10]. Interest rates on loans are also gaining importance for future NPLs, which implies the importance of interest rate policies. Baboučak and Jančar [35] report similar results.

In the case of GDP per capita, the prevailing degree of explanation remains on the part of own (earlier) changes from the 1 st quarter $(96.1 \%)$ to the 20th quarter (83.8\%). Nevertheless, in terms of the explanation of GDP per capita, the share of nonperforming loans is gaining importance. Their share has been growing since the first quarter $(3.9 \%$ to 7.1\%). Moreover, the degree of explanation of GDP per capita by NPLs is higher than, for example, by real salaries (from $0.0 \%$ to $2.9 \%$ ) or interest rates on loans (from $0.0 \%$ to $6.1 \%$ ). These results confirm the importance of lowering the NPL in the banking system for maintaining GDP per capita. The results are supported, among others, by Louzis, Vouldis and Matexes [15] (Fig. 6).

Fig. 6 The decomposition of variance for NPL and GDPpc

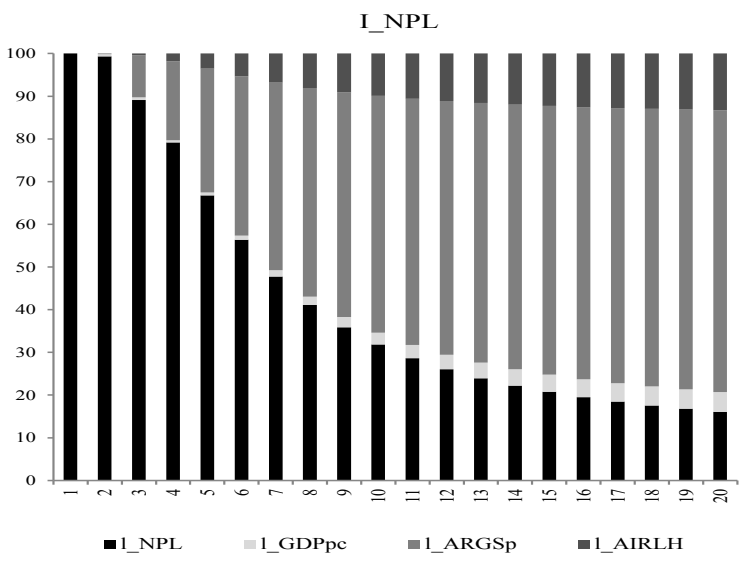




\section{I_GDPpc}

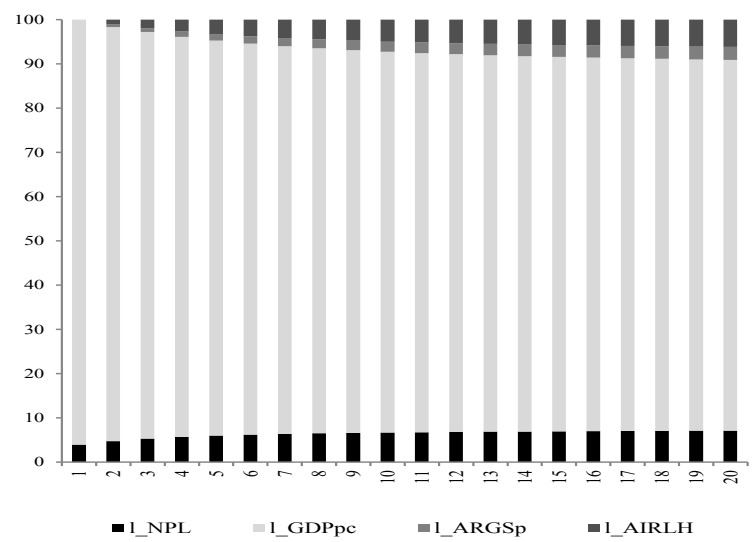

In summary, the results of the impulse response function and the variance decomposition analysis more clearly indicate that the changes in NPLs are influenced by the current creditworthiness and its changes throughout the entire loan period. This is mainly evidenced by the growing importance of relative salaries (ARGSp). Changes in interest rates on loans are of a significant stabilizing importance for NPLs. The low interest rate policy pursued by the NBP for several years has had a positive effect on the stabilization of interest rates on commercial banks' loans.

\section{Conclusion}

Although most authors examine the determinants of NPL for an entire loan portfolio, these authors have focused on a specific loan portfolio, i.e., for households, to get precise results. The reason for the analysis of NPLs for householdd is their over $40 \%$ share in the total loan portfolio in Poland. According to the authors, each change in the structure of the loan portfolio requires knowledge of the NPL determinants, separately for household and corporate loans. The NPL analysis for households focuses on the variables determining the financial situation and creditworthiness, e.g., the amount of GDP per capita, real salaries and loan servicing costs.

In line with the aim of the article, the results of the analysis confirm a reduction in NPL rates for household loans in Poland in 2009-2021. These rates were on average by $2 \mathrm{pp}$. lower than for corporate loans. The decline in NPLs, i.e., an improvement in portfolio quality, was explicated with the decline in interest rates on loans to households. The results of the VECM and the level of the EC1 ratio indicate that in the long run, NPLs are most affected by deviations in earlier periods. These results confirm a real continued deterioration of creditworthiness in the subsequent periods. If there is a loss of creditworthiness, then a longer time is required to recover it. The sign of the EC1 factor indicates a negative relation of GDPpc and real income from NPLs. There is a positive relationship between interest rates on loans and non-performing loans.

The results of the response function indicate negative NPL responses to impulses (earlier) NPL fluctuations and real salaries. NPLs react positively to the per capita GDP and loan interest rate impulse. With an increase in GDP per capita, the demand for loans may increase and thus the share of nonperforming loans expands. Increased loan concentration rates, due to the higher costs of loan servicing, contribute to an increase in NPL. The results of the variance decomposition suggest a significant degree of explanation of NPL by real salaries. Their share grows to $66 \%$ in the forecast period of 20 quarters. This result confirms the validity of the current salary (income) for the capability of servicing the loan. The NPL is also explained by previous changes to the NPL, i.e., the condition of non-performing loans (16.1\%), the interest rate on loans $(13.3 \%)$ and, to a lesser extent, GDP per capita (4.6\%). This means the necessity to constantly monitor non-performing loans and the interest rate policy pursued by the NBP and commercial banks. The decomposition of GDP per capita also shows the importance of controlling NPLs (up to $7.1 \%$ ) and loan concentration rates $(6.2 \%)$. Thus, the impact of the quality of the loan portfolio on the conditions of economic development, measured with GDP per capita, is confirmed.

To conclude, the income situation of borrowers, depending on the pace of salary growth and the decline in the unemployment rate in Poland, is of general importance to lowering the NPLs (i.e., limiting the negative consequences for the economy). The authors' contribution to the NPL analysis is to draw attention to the importance of changes in the structure of the loan portfolio and the different determinants of NPLs for household loans and, for example, for enterprises in individual countries. The NPL reduction for household loans in Poland relies on increasing relative salaries and the ongoing restructuring of non-performing loans. The importance of loan interest rates has been confirmed 
for NPLs, but their degree of explanation for NPL changes is nearly 5 times weaker than for real salries. Thus, our research results broaden the knowledge about the quality of the loan portfolio and have significant implications for bank efficiency, market stability and economic growth in the economy, and the role of macroeconomic policy.

\section{References:}

[1] G.J.D.G Souza, C.AFeijó, Credit risk and macroeconomic interactions: empirical evidence from the Brazilian banking system, Modern Economy, Vol.2, No. 5, 2011, pp. 910929, doi: 10.4236/me.2011.25102.

[2] A.T. Vouldis, D. P. Louzis, Leading indicators of non-performing loans in Greece: the information content of macro-, micro- and bank-specific variables,Empirical Economics,Springer Berlin Heidelberg, Vol.54,No.3, 2018, pp.1187-1214, doi:10.1007/s00181-017-1247-0.

[3] R. Stijepović, Recovery and reduction of nonperforming loans - podgorica approach, Journal of Central Banking Theory and Practice, Vol. 3, No. 3, 2014, pp.101-118, doi: 10.2478/jcbtp-2014-0017.

[4] H. A. Qudah, K. K. Abdo, L.A. Al_Qudah, O. Kilani, M. Almanaseh, M. Alqudah, Liquidity Risk Measurement Study Case (Jordan Islamic Banks), International Journal of Economics and Management Systems, No. 6, 2021, pp. 495-503.

[5] J. Kasinger, J. P. Krahnen, S. Ongena, L. Pelizzon, M. Schmeling, M. Wahrenburg, NonPerforming Loans - New Risks and Policies? NPL Resolution After COVID-19: Main Differences to Previous Crises, European Parliament, Economic Governance Support Unit (EGOV) Directorate-General for Internal Policies PE 651.387, March, 2021, Retrieved from: https://www.europarl. europa.eu/ Reg Data/etudes/STUD/2021/ 651387/IPOL STU (2021)651387_EN.pdf.

[6] NBP, Assets and Liabilities of Monetary Financial Institutions, 2021, Retrieved from: https://www.nbp.pl/homen.aspx?f=/en/statysty $\mathrm{ka} /$ zobowiazania.html.

[7] BIS 2021. Statistics Explorer. Retrieved from: http://stats.bis.org:8089/statx/srs/table/ f3.1? $\mathrm{f}=\mathrm{xlsx}$.

[8] M. Marcinkowska, P. Wdowiński, S. Flejterski, S. Bukowski, M. Zygierewicz, Wpływ
Regulacji Sektora Bankowego Na Wzrost Gospodarczy - Wnioski Dla Polski (The impact of banking sectorregulation on economicgrowth-conclusions for Poland), Materiały i Studia, NBP, No. 35, Warsaw, 2014, Retrived from: https://www.nbp.pl/ publikacje/materialy_i_studia/ms305.pdf.

[9] A. Kosztowniak, Changes in The Quality of The Loan Portfolio in The Polish Banking System, Journal of Economics, Business \& Organization Research, CEBOR Academy Ltd., Italy, 2020, Retrieved from: https://dergipark.org.tr/en/download/articlefile/1470997.

[10] V. Salas, J. Saurina, Credit Risk in Two Institutional Regimes: Spanish Commercial and Savings Banks. Journal of Financial Services Research, No. 22, 2002, pp. 203-224. Available online: https://link.springer.com/article/10.1023/A:101 9781109676 (accessed on 17 May 2020).

[11] H. Fofack, Non-performing Loans in SubSaharan Africa: Causal Analysis and Macroeconomic Implications. World Bank Policy Research Working Paper, No. 3769, 2005.

[12] T. Hada, N. Bărbuță-Mișu, I.C. Iuga, D. Wainberg, Macroeconomic Determinants of Nonperforming Loans of Romanian Banks, Sustainability, 2020, No.12, 7533. https://doi.org/10.3390/su12187533

[13] N. Klein, Non-Performing Loans in CESEE: Determinants and Impact on Macroeconomic Performance, IMF Working Paper European Department, No. 13/72, 2013.

[14] I. Mazreku, F. Morina, V. Misiri, J. V. Spiteri, S. Grima, Determinants of the Level of NonPerforming Loans in Commercial Banks of Transition Countries, European Research Studies Journal, Vol. XXI, Issue 3, 2018, pp. 313.

[15] D. P. Louzis, A. T. Vouldis, V. L. Metaxas, V.L., Macroeconomic and Bank-Specific Determinants of Non-performing Loans in Greece: A Comparative Study of Mortgage, Business and Consumer Loan Portfolios. Elsevier, Journal of Banking and Finance, No. 36(4), 2012, pp. 1012-1027.

[16] C. Zaman, B. Meunier, A Decade of EU Membership: Evolution of Competitiveness in Romania. European Research Studies Journal, No. 20(2A), 2017, pp. 224-236. 
[17] M. Nkusu, Nonperforming Loans and Macro Financial Vulnerabilities in Advanced Economies. IMF Working Papers, 161, 2011.

[18] C. J. Godlewski, Bank Capital and Credit Risk Taking in Emerging Market Economies, Journal of Banking Regulation, Vol. 6, No. 2, 2008, pp. 128-145, doi: 10.1057/palgrave.jbr.2340187.

[19] A. Boudriga, N.B. Taktak, S. Jellouli, Bank Specific, Business and Institutional Environment Determinants of Banks Nonperforming Loans: Evidence from MENA Countries, Economic Research Forum, Working Paper, 2010, pp. 1-28.

[20] A. Dimitrios, L. Helen, T. Mike,Determinants of Non-Performing Loans: Evidence from Euro-Area Countries, Finance Research Letters, Elsevier, Vol. 18, 2016, pp. 116-119, doi: 10.1016/j.frl.2016.04.008.

[21] R. A. Rachman, Y.B.Kadarusman, K.Anggriono, R.Setiadi,Bank-Specific Factors Affecting Non-Performing Loans in Developing Countries: Case Study of Indonesia, The Journal of Asian Finance, Economics and Business (JAFEB), Vol. 5, No. 2, 2018, pp. 3542.

[22] A.N. Berger, R. de DeYoung,Problem Loans and Cost Efficiency, Journal of Banking and Finance, Vol. 21, 1997, pp.1-28.

[23] F. Fiordelisi, D. Marques-Ibanez, P. Molyneux, Efficiency and Risk in European Banking, Journal of Banking and Finance, Elsevier, Vol. 35, No. 5, 2011, pp. 1315-1326.

[24] R. Rajan, Why bank credit policies fluctuate, The Quarterly Journal of Economics, Vol. 2, No. 109, 1994, pp. 399-441.

[25] V. Makri, A. Tsagkanos, A. Bellas, Determinants of Non-Performing Loans: The Case of Eurozone, Panoeconomicus, Vol. 61, No. 2, 2014, pp. 193-206.

[26] F.D. Constant, A. Ngomsi, Determinants of Bank Long-Term Lending Behavior in The Central African Economic and Monetary Community (CEMAC), Review of Economics and Finance, Better Advances Press, Canada, Vol. 2, 2012, pp. 107-114.

[27] W. Anjom, A.M. Karim, Relationship Between Non-Performing Loans and Macroeconomic Factors (With Specific Factors: A Case Study on Loan Portfolios- SAARC Countries Prospective. Asia Pacific Journals of Finance and Risk Management. No.15(3), 2016, pp. 84103.

[28] A. Dimitrios, L. Helen, T. Mike,Determinants of Non-Performing Loans: Evidence from Euro-Area Countries, Finance Research Letters, Elsevier, Vol. 18, 2016, pp. 116-119, doi: 10.1016/j.frl.2016.04.008.

[29] H. Y. Khudhair, A. Mardani, The Major Issues Facing Staff in Islamic Banking Industry, International Journal of Economics and Management Systems, No. 6, 2021, pp. 200211.

[30] H. Meshref, Predicting Loan Approval of Bank Direct Marketing Data Using Ensemble Machine Learning Algorithms, International Journal of Circuits, Systems and Signal Processing, Vol. 14, 2020, pp. 914-922.

[31] IMF, Financial Soundness Indicators Background Paper, Prepared by the Staff of the Monetary and Financial Systems and Statistics Departments. Approved by C. S. Carson, S. Ingves, May 13, 2003, p. 49.

[32] K. Matthewes, J. Guo, N. Zhang, Rational inefficiency and non-performing loans in Chinese banking: a nonparametric bootstrapping approach, Cardiff Economic Working Papers, E2007/5, Cardiff University, U.K, 2007.

[33] B. Maggi, M. Guida, Modelling nonperforming loans probability in the commercial banking system: efficiency and effectiveness related to credit risk in Italy, Empirical Economics, No. 41, 2011, pp. 269-291.

[34] M. Piłatowska, Modelowanie Niestacjonarnych Procesów Ekonomicznych. StudiumMetodologiczne, (Modelling of NonStationary Economic Processes. A Methodological Study), Uniwersytet M. Kopernika, Toruń, 2003.

[35] I. Babouček, M. Jančar, Effects of Macroeconomic Shocks to the Quality of the Aggregate Loan Portfolio; Working Paper Series, No. 1; Czech National Bank: Praha, Czech, 2005. 
Contribution of individual authors to the creation of a scientific article (ghostwriting policy)

Sławomir I. Bukowski was responsible for the econometric analysis.

Aneta M. Kosztowniak carried out the concepts, review of literature and research, preparation of statistical data, interpretation of research results and figures, tables and full paper preparation.

\section{Sources of funding for research presented in a scientific article or scientific article itself}

The funding for the article was sourced from the Kazimierz Pulaski University of Technology and Humanities in Radom.

\section{Creative Commons Attribution}

\section{License 4.0 (Attribution 4.0}

\section{International , CC BY 4.0)}

This article is published under the terms of the Creative Commons Attribution License 4.0 https://creativecommons.org/licenses/by/4.0/de ed.en_US 


\section{Annex}

Table 1. Model variables and expected impact on the NPLs

\begin{tabular}{|l|c|c|c|}
\hline No. & Variables & Data source & Impact \\
\hline 1 & $N P L_{t}$ & NPB & “-“ \\
\hline 2 & $G D P p c_{t}$ & OECD & "-“ \\
\hline 3 & $A R G S p_{t}$ & CSO & "-“ \\
\hline 4 & $A I R L H_{t}$ & NBP & "+ “ \\
\hline
\end{tabular}

\section{Table 2.The VECM model}

\begin{tabular}{|c|c|c|c|c|}
\hline \multicolumn{5}{|c|}{$\begin{array}{l}\text { VECM system, lag order 2, observations 2009:4-2021:2 }(\mathrm{T}=47) \\
\text { Cointegration rank = 1, Case 3: Unrestricted constant }\end{array}$} \\
\hline \multicolumn{3}{|c|}{$\beta$ (cointegrating vectors, standard errors in parenthes) } & \multicolumn{2}{|c|}{$\alpha($ adjustment vectors $)$} \\
\hline 1 NPL & 1 & 0 & 1 NPL & - \\
\hline 1_GDPpc & 0.59541 & 0.09616 & 1_GDPpc & -0.001559 \\
\hline 1_ARGSp & 2.26960 & 0.63079 & 1_ARGSp & -0.000708 \\
\hline d_AIRLH & -9.91650 & 3.08760 & d_AIRLH & 0.0043201 \\
\hline \multicolumn{5}{|c|}{ Equation 1: d_l_NPL } \\
\hline & Coefficient & Std. Error & t-ratio & p-value \\
\hline const & 5.364580 & 0.741312 & 7.237 & $\begin{array}{l}<0.0001 * * \\
*\end{array}$ \\
\hline d_1_NPL_1 & -0.211794 & 0.115883 & -1.828 & $0.0753 *$ \\
\hline d_1_GDPpc_1 & 0.116180 & 0.260513 & 0.446 & 0.6581 \\
\hline d_1_ARGSp_1 & 0.671921 & 0.357612 & 1.879 & $0.0677^{*}$ \\
\hline d_d_AIRLH_1 & -3.582050 & 1.631590 & -2.195 & $0.0341 * *$ \\
\hline EC1 & -0.386595 & 0.053413 & -7.238 & $\begin{array}{l}<0.0001 * * \\
*\end{array}$ \\
\hline Mean dependent var & 0.002563 & S.D. dependent var & & 0.037236 \\
\hline Sum squared resid & 0.024165 & S.E. of regression & & 0.024892 \\
\hline $\mathrm{R} 2$ & 0.603911 & Adjusted R2 & & 0.553131 \\
\hline rho & -0.098803 & DW & & 2.196533 \\
\hline \multicolumn{5}{|c|}{ Equation 2: d_l_GDPpc } \\
\hline & Coefficient & \begin{tabular}{|c|} 
Std. Error \\
\end{tabular} & t-ratio & p-value \\
\hline const & 0.032466 & 0.569975 & 0.0569 & 0.9549 \\
\hline d_1_NPL_1 & -0.015615 & 0.089099 & -0.1753 & 0.8618 \\
\hline d_1_GDPpc_1 & -0.420778 & 0.200302 & -2.1010 & $0.0422 * *$ \\
\hline d_1_ARGSp_1 & 0.128208 & 0.274959 & 0.4663 & 0.6436 \\
\hline d_d_AIRLH_1 & -0.178242 & 1.254490 & -0.1421 & 0.8877 \\
\hline EC1 & -0.0015586 & $\begin{array}{r}0.041068 \\
\end{array}$ & -0.0379 & 0.9699 \\
\hline Mean dependent var & 0.007534 & S.D. dependent var & & 0.019791 \\
\hline Sum squared resid & 0.014285 & S.E. of regression & & 0.019139 \\
\hline $\mathrm{R} 2$ & 0.171145 & Adjusted R2 & & 0.064881 \\
\hline rho & -0.022234 & DW & & 2.013226 \\
\hline \multicolumn{5}{|c|}{ Equation 3: d_l_ARGSp } \\
\hline & Coefficient & Std. Error & t-ratio & p-value \\
\hline const & 0.009756 & 0.342660 & 0.0285 & 0.9774 \\
\hline d_1_NPL_1 & -0.004598 & 0.053565 & -0.086 & 0.9320 \\
\hline d_1_GDPpc_1 & 0.021279 & 0.120418 & 0.177 & 0.8607 \\
\hline d_1_ARGSp_1 & -0.279071 & 0.165301 & -1.688 & $0.0993^{*}$ \\
\hline d_d_AIRLH_1 & -0.589286 & 0.754179 & -0.781 & 0.4393 \\
\hline EC1 & -0.000708 & $\begin{array}{r}0.024689 \\
\end{array}$ & -0.029 & 0.9773 \\
\hline Mean dependent var & 0.000044 & S.D. dependent var & & 0.011424 \\
\hline Sum squared resid & 0.005163 & S.E. of regression & & 0.011506 \\
\hline
\end{tabular}




\begin{tabular}{|c|c|c|c|c|}
\hline R2 & 0.100925 & \multicolumn{2}{|l|}{ Adjusted R2 } & -0.014341 \\
\hline rho & -0.037395 & DW & & 2.070443 \\
\hline \multicolumn{5}{|c|}{ Equation 4: d_d_AIRLH } \\
\hline & Coefficient & \begin{tabular}{|l} 
Std. Error \\
\end{tabular} & t-ratio & p-value \\
\hline const & -0.0600174 & 0.0923611 & -0.6498 & 0.5196 \\
\hline d_1_NPL_1 & 0.0002609 & 0.0144381 & 0.0181 & 0.9857 \\
\hline d_1_GDPpc_1 & 0.0106305 & 0.0324577 & 0.3275 & 0.7450 \\
\hline d_1_ARGSp_1 & -0.0183039 & 0.0445554 & -0.4108 & 0.6835 \\
\hline d_d_AIRLH_1 & -0.1975700 & 0.2032820 & -0.9719 & 0.3371 \\
\hline EC1 & 0.0043201 & 0.00665476 & 0.6492 & 0.5200 \\
\hline Mean dependent var & -0.000011 & \multicolumn{2}{|l|}{ S.D. dependent var } & 0.002994 \\
\hline Sum squared resid & 0.000375 & \multicolumn{2}{|l|}{ S.E. of regression } & 0.003101 \\
\hline $\mathrm{R} 2$ & 0.048738 & \multicolumn{2}{|l|}{ Adjusted R2 } & -0.073219 \\
\hline rho & -0.031491 & \multicolumn{2}{|l|}{ DW } & 2.019588 \\
\hline
\end{tabular}

Nonte: $\alpha=0.01(* * *)$, where $\alpha=0.05(* *), \alpha=0.10\left(^{*}\right)$. 